\title{
Engineering Properties of Bauxite Residue
}

\author{
Anastasios Mouratidis*, Panagiotis Nikolidakis \\ Civil Engineering Department, Aristotle University of Thessaloniki, Thessaloniki 54124, Greece
}

Corresponding Author Email: anmourat@ civil.auth.gr

https://doi.org/10.18280/ijsdp.150308

Received: 28 December 2018

Accepted: 3 December 2019

\section{Keywords:}

bauxite residue, characteristic,

engineering, strength, test

\begin{abstract}
Bauxite residue is a by-product of alumina refining from bauxite ore according to the Bayer process. During the last two decades, potential use of this by-product in highway engineering projects, which engage big volumes of earthwork, has been investigated through laboratory research and site application. Investigation of bauxite residue properties by different research institutes produced varying chemical composition, values of physical characteristics and strength features. Comparing these research results worldwide, one can easily notice the significant irregularity, attributed, in the first place, to the bauxite ore. However, there are probably, other reasons, as well, which make these test results and, especially, the strength test results, difficult to interpret and, probably, non-comparable. This scientific article presents an overview of chemical analyses and test results on physical and strength properties of bauxite residue worldwide. It also attempts an exploration of the reasons for the disparity of values encountered in the international literature. Moreover, the article presents a recipe to enhance the strength properties of bauxite residue with view to utilising the byproduct for engineering purposes. Two pilot engineering projects, introducing bauxite residue as main construction material, are herewith outlined. The unprecedented success of the pilot projects linked to the excellent performance of the bauxite residue structures pointed out the prospective benefits from the use of this by-product in engineering.
\end{abstract}

\section{INTRODUCTION}

Industrial activities and production are dependent on regular and unceasing supply of raw materials. In the same line, construction engineering also needs materials: aggregates, pipe conduits, concrete and bitumen. These materials may often be abundant and inexpensive but, in some countries, such as Western European countries and regions, may also be rare and costly. In these cases, it seems mandatory to search for other potential sources of raw materials to feed engineering activities and projects.

During the last decades, the concept of recycling gained popularity and recycling practices expanded to new fields of application. Retrieving and reusing secondary materials constitutes nowadays a common practice in civil engineering and, especially, in road engineering [1]. In this context, asphalt pavement recycling is a well-known, popular technique in most developed and developing countries [2].

The need for recycling in road engineering is dictated not only by the scarcity or the cost of raw materials but also by the satisfactory performance of several by-products. It has been proved by laboratory investigation and, much more, by multiple engineering applications that several recycled or secondary materials may be resistant and durable, fully suitable for engineering purposes [3]. In this category, fly ash, a major industrial by-product, may be used as a hydraulic binder, partly or totally replacing Portland cement [4]. Moreover, steel slags [5], waste glass [6] and rubber tyres [7] have been used as alternative materials in road engineering. Potential use of these alternative materials in engineering applications offers environmental benefits, on regional scale, by reducing landfill need, and technico-economic benefits, on the scale of a specific engineering project, by introducing structural constituents of low cost and high performance. In this regard, research on the engineering properties of these secondary materials is of utmost importance.

Bauxite residue (BR) is a rather unknown, in the engineering field, secondary material. BR, also known as red mud, is the remainder of bauxite treatment according to the Bayer process. This secondary material, usually in a semifluid state, is produced in big quantities at the aluminium production industrial plants worldwide. Estimates raise global annual production of BR to 150 million tons. International literature indicates that the largest part of the by-product is disposed following environmental-unfriendly methods in all producing countries [8-10].

BR materials have been investigated with view to producing not only ceramics and bricks but also for iron recovery $[9,11,12]$. Rarer are the research attempts to establish a consistent frame for the application of the byproduct in engineering projects $[9,10,12,13]$. In fact, during the last two decades, relevant research has been intensified in many bauxite producing countries (USA [7], India [14], Australia [15] and China [16]). However, it seems that these long-lasting research efforts did not produce the expected results, since there is little evidence of real engineering structures built of BR.

The Aristotle University of Thessaloniki (AUTH) started exploring the properties of $\mathrm{BR}$ and possible engineering applications in the 1990s. Research was orientated to 
physical and to strength properties of the by-product and of its mixtures with natural soils and aggregates [17]. Research findings over time and, especially, the installation of an industrial filter press, which permits the recovery of the solid fraction of BR, helped push forward the implementation of an innovative recycling technique and led to the realisation of two pilot projects introducing BR as the main construction material. Similar research on a fraction of the byproduct, called 'red sand', has been undertaken by the Curtin University, in Australia [15, 18]. The mixture applied consisted of red sand and two pozzolanic activators, fly ash and limekiln dust, with excellent results.

However, throughout the international literature about BR properties $[12,19,20]$ and, especially, about strength characteristics [8, 21-24], the disparity of test results is enormous: CBR values ranging from 2 to 67 and unconfined compression strength from 1.4 to $5.6 \mathrm{~kg} / \mathrm{cm}^{2}$. Is this variation exclusively due to the heterogeneity of the material or are there other reasons related to the conditions of laboratory testing in each case? In the present article, the reasons of this disparity are investigated and an approach to correct interpretation of test results is outlined.

\section{CHEMICAL COMPOSITION OF BR}

BR produced at the industrial site of 'Aluminium of Greece' may attain an annual rate of 700,000 tons. Besides the current practice of disposal to the seabed and to artificial lagoons, some other fields of re-utilisation are also in progress: use in cement production as a pigment, extraction of metals by secondary processing and manufacturing of ceramics by the brick industry.

The chemical composition of the by-product varies with the bauxite ore origin. Iron, aluminium, silicon and calcium oxides constitute the core of the chemical structure of BR. Laboratory testing by AUTH for more than 20 years [17, 25] indicates a significant heterogeneity of the by-product (Table 1) while the concentration of its main constituents presents an important variation over time. This variation is attributed not only to the heterogeneity of the local bauxite ore but also to the characteristics of imported bauxite ore, mixed with the local raw material for the production of alumina. It seems, however, that the range of this variation is much wider on a worldwide scale [19].

Laboratory tests on $\mathrm{BR}$ provided loss on ignition values $\mathrm{LOI}=5-12 \%$ while alkalinity was found $\mathrm{pH}=10.8-12.5[26]$.

Table 1. Chemical composition of BR of different origin

\begin{tabular}{|c|c|c|c|c|c|c|c|c|c|c|}
\hline \multirow{2}{*}{$\begin{array}{c}\text { Chemical } \\
\text { Compositio } \\
\text { n } \\
(\%)\end{array}$} & \multicolumn{3}{|c|}{$\begin{array}{c}\text { "Aluminium of } \\
\text { Greece" }\end{array}$} & \multirow{2}{*}{$\begin{array}{c}\text { WORLWID } \\
\text { E } \\
\text { (Capron) } \\
1998\end{array}$} & \multirow{2}{*}{$\begin{array}{c}\text { GREAT } \\
\text { BRITAI } \\
\text { N } \\
\text { (Newson) } \\
2014 \\
\end{array}$} & \multirow{2}{*}{$\begin{array}{c}\text { INDIA } \\
\text { (Mohapatra } \\
\text { ) } \\
\mathbf{2 0 0 0}\end{array}$} & \multirow{2}{*}{$\begin{array}{c}\text { INDIA } \\
\text { (Kishan } \\
\text { ) } \\
2017\end{array}$} & \multirow{2}{*}{$\begin{array}{c}\text { CHIN } \\
\text { A } \\
\text { (Wang) } \\
2012\end{array}$} & \multirow{2}{*}{$\begin{array}{c}\text { HUNGAR } \\
\text { Y } \\
\text { (Szepvolgyi } \\
\text { ) } \\
2011 \\
\end{array}$} & \multirow{2}{*}{$\begin{array}{c}\text { AUSTRALI } \\
\text { A } \\
\text { (Klauber) } \\
2009\end{array}$} \\
\hline & $\begin{array}{c}1994 \\
- \\
2002\end{array}$ & $\begin{array}{c}2008 \\
- \\
2012\end{array}$ & $\begin{array}{c}2008 \\
- \\
2012\end{array}$ & & & & & & & \\
\hline $\mathrm{Fe}_{2} \mathrm{O}_{3}$ & 35 & 47 & 45 & $30-60$ & 36 & 27 & 34 & 26 & 37 & 41 \\
\hline $\mathrm{Al}_{2} \mathrm{O}_{3}$ & 28 & 14 & 18 & $10-20$ & 23 & 41 & 20 & 19 & 14 & 16 \\
\hline $\mathrm{SiO}_{2}$ & 6 & 9 & 7 & $3-50$ & 18 & 3 & 8 & 9 & 20 & 10 \\
\hline $\mathrm{CaO}$ & 6 & 12 & 9 & 2-8 & 4 & trace & 4 & 22 & 8 & 9 \\
\hline $\mathrm{TiO}_{2}$ & 6 & 5 & 5 & trace- 15 & 6 & 3 & 15 & 7 & 4 & 9 \\
\hline $\mathrm{Na}_{2} \mathrm{O}$ & & 1 & 3 & $2-10$ & 12 & 0.4 & 5 & 4 & 5 & 4 \\
\hline $\mathrm{SO}_{2}$ & & & & & 1 & 3 & & & & \\
\hline Other & 9 & 5 & & & & & 3 & & & \\
\hline LOI & 10 & 7 & 9 & & & & 11 & 10 & 12 & 10 \\
\hline
\end{tabular}

Comparison of chemical composition of BR from aluminium industrial plants worldwide $[10,13,16,17,19,22$, $23,27]$ unveils serious heterogeneity of the by-product. It seems that it is the BR, containing high concentrations of iron and calcium oxides, which exhibits high strength performance in engineering projects.

The variation in chemical composition with time is obvious in BR produced at the 'Aluminium of Greece' industrial plant. The more recent tailings are richer in iron oxide and this is probably the reason of the strength evolution and noticeable increase in resistance of the by-product during the second stage of research (2008-2012).

\section{PHYSICAL PROPERTIES AND CLASSIFICATION}

$\mathrm{BR}$ is a soil-like material of deep red colour having an average particle size $<10 \mu \mathrm{m}$. The gradation curve of the material was determined by laboratory analyses according to European Standards. Laboratory tests on samples of different origin confirmed slight variation in the gradation curve of the material presenting a major fraction smaller than $45 \mu \mathrm{m}$ (Table 2).

While comparing sieve size analyses (Table 2), the BR produced by the 'Aluminium of Greece' presents a slightly coarser gradation than other similar materials. This may also lead to higher strength values.

Table 2. Sieve size analysis of BR: percent passing [10, 16, 17, 20, 22, 23, 27]

\begin{tabular}{ccccccc}
\hline $\begin{array}{c}\text { Sieve- } \\
\text { Size }\end{array}$ & $\begin{array}{c}\text { "Aluminium } \\
\text { of Greece" }\end{array}$ & $\begin{array}{c}\text { INDIA Bhopal } \\
\text { (Kishan, 2017) }\end{array}$ & $\begin{array}{c}\text { INDIA Nalco } \\
\text { (Das, 2015) }\end{array}$ & $\begin{array}{c}\text { CHINA } \\
\text { (Wang, 2012) }\end{array}$ & $\begin{array}{c}\text { G. BRITAIN } \\
\text { (Newson, 2014) }\end{array}$ & $\begin{array}{c}\text { HUNGARY } \\
\text { (Szepvolgyi, 2011) }\end{array}$ \\
\hline No 10 & 100 & 100 & 99 & 100 & 100 & 100 \\
No 40 & $95-100$ & 99 & 99 & 100 & 100 & 100 \\
No 100 & $90-95$ & 90 & 97 & 100 & 100 & 99 \\
No 200 & $84-86$ & 85 & 92 & 98 & 98 & 93 \\
45 $\mu \mathrm{m}$ & 80 & 76 & 62 & 86 & 96 & 72 \\
\hline
\end{tabular}


Table 3. Physical properties of BR $[8,17,20,21,23]$.

\begin{tabular}{|c|c|c|c|c|c|c|}
\hline \multirow{2}{*}{ Physical Properties } & \multicolumn{2}{|c|}{ "ALUMINIUM OF GREECE" } & \multirow{2}{*}{$\begin{array}{l}\text { INDIA Bhopal } \\
\text { (Kishan, 2017) }\end{array}$} & \multirow{2}{*}{$\begin{array}{l}\text { INDIA Nalco } \\
\text { (Das, 2015) }\end{array}$} & \multirow{2}{*}{$\begin{array}{c}\text { G. BRITAIN } \\
\text { (Newson, 2014) }\end{array}$} & \multirow{2}{*}{$\begin{array}{c}\text { USA (Gore, } \\
\text { 2015) }\end{array}$} \\
\hline & 1994-2002 & 2008-2012 & & & & \\
\hline \multicolumn{7}{|l|}{ ATTERBERG LIMITS } \\
\hline WL & 37 & 37 & 44 & 24 & 54 & 43 \\
\hline WP & 28 & 33 & 34 & 17 & 40 & 30 \\
\hline IP & 9 & 4 & 10 & 7 & 14 & 13 \\
\hline \multicolumn{7}{|l|}{ PERMABILITY (cm/s) } \\
\hline uncompacted & - & $3 \times 10^{-5}$ & & & & \\
\hline compacted & - & $5 \times 10^{-7}$ & & $7 \times 10^{-7}$ & & \\
\hline SPECIFIC GRAVITY $\left(\mathrm{t} / \mathrm{m}^{3}\right)$ & 3.4 & 3.8 & 3.1 & 3.3 & 3.1 & \\
\hline \multicolumn{7}{|l|}{ PROCTOR TEST } \\
\hline $\mathrm{W}_{\mathrm{opm}}(\%)$ & 24 & 25 & 33 & & & \\
\hline$\gamma_{\mathrm{d}(\max )}$ & 1.7 & 1.7 & 1.6 & & & \\
\hline
\end{tabular}

BR is a soil-like material consisting of fine grains. However, tests in the AUTH, and also worldwide, confirm low plasticity (Table 3). This may be attributed to the uniformity of grains and also to the strong presence of iron oxide, which does not generate plastic performance of the residue $[17,21]$.

Laboratory testing did not lead to the determination of sand equivalent. Permeability is low in stockpiles and even lower after compaction of the material (Table 3). However, due to its relatively coarse gradation, BR produced in Greece is not a totally impermeable material $(\mathrm{k}<10-7 \mathrm{~cm} / \mathrm{s})$ as other $\mathrm{BR}$ around the globe. In general, according to the USCS, BR is classified as a silt of low plasticity (ML).

\section{STRENGTH PROPERTIES}

Laboratory testing for the determination of BR strength properties usually includes CBR experiments, unconfined compression, triaxial and shear box tests. Specimens are compacted in line with the Proctor test findings prior to undergo loading and shear in the laboratory. Normal and modified Proctor procedures are both used in different research institutes.

Soaking conditions may play a significant role in the development of material strength. In most cases, soaked specimens exhibit a much inferior performance with respect to unsoaked specimens.

In an attempt to present an overview of strength parameter values, research findings of different research institutes worldwide are gathered (Table 4). It must be underlined that most institutes choose to perform only one kind of test to evaluate the mechanical strength of the by-product, the most suitable to the ongoing engineering project.

At the Aristotle University, tests were carried out in the laboratory to determine the strength parameters of the byproduct, namely Proctor/CBR tests and unconfined compression tests, under different soaking conditions (Table 4). Some tests on the shear box were also performed. At the initial stage of research activities (1994-2002), specimens were composed either of BR or of a mixture of BR with fly ash $[17,25]$. In several cases, BR was reinforced by bauxite chippings $(1-2 \mathrm{~cm})$ to improve strength properties of the material. During the second stage of research (2008-2012), the by-product was processed at the industrial filter press prior to be submitted to laboratory testing and to be introduced as construction material in pilot projects $[22,26]$. Improvement in strength properties was impressive (Table 4).

The overview of test results in Table $4[14,17,20,22-24$,
27] confirms high disparity of strength characteristics of the by-product. One may wonder if this is reasonable and may try to identify the reasons for this disparity. A first reason is, certainly, the heterogeneity of the material. It seems that a material poor in iron oxide $\left(\mathrm{Fe}_{2} \mathrm{O}_{3}\right)$ does not develop high strength. Less obvious is the effect of $\mathrm{CaO}$ but, still, poor in calcium oxide materials are deficient in structural strength. As by general rule, the more the material deviates from ordinary soils, the higher is the strength.

In general, site observations and condition assessment of real structures are the best confirmation of research findings. Loose deposits of BR (Figure 1) in the vicinity of the industrial plant seem to repose at an angle of $\sim 40 \mathrm{o}$, a quite high strength value for a mud-like material, thus confirming the results of shear strength tests by the AUTH (Table 4).

Gradation plays also a reasonable role: coarser materials exhibit higher strength. Moreover, laboratory testing conditions and additives may significantly alter and improve strength properties.

Generally, prior to be submitted to test loading, BR specimens are subject to Proctor testing, either normal or modified. Some laboratories are able to apply both methods. In the AUTH laboratory, only the modified method is applied, which leads to higher values of dry density and lower values of optimum moisture. Accordingly, materials compacted according to the modified test are likely to exhibit higher strength values. On the other hand, it is safer to determine CBR at $90 \%$ of dry density if the compaction equipment and the overall site conditions do not advocate for high compaction degree.

Cylindrical specimens for unconfinedd compression test must be shaped at a ratio of $h / d=2$, where $h$ the height and $d$ the diameter of the specimen. Test results on specimens of different shape must be suitably converted to equivalent values for specimens of $h / d=2$.

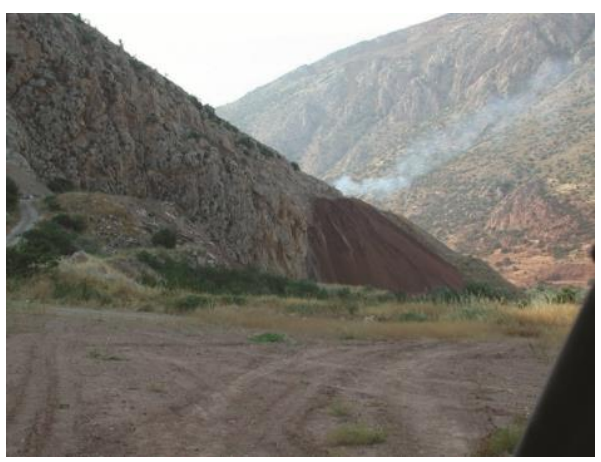

Figure 1. BR deposits 
Table 4. Strength properties of BR

\begin{tabular}{|c|c|c|c|c|c|c|c|}
\hline \multirow[t]{2}{*}{ Industry-Country } & \multirow[t]{2}{*}{ MATERIAL } & \multicolumn{2}{|c|}{ Uniaxial loading } & \multirow[t]{2}{*}{ REMARKS } & \multirow[b]{2}{*}{$\begin{array}{c}\text { c (cohesion) } \\
\left(\mathrm{kg} / \mathrm{cm}^{2}\right)\end{array}$} & \multirow[b]{2}{*}{$\begin{array}{c}\varphi \\
\text { (friction) } \\
\left({ }^{\circ}\right)\end{array}$} & \multirow[t]{2}{*}{ REMARKS } \\
\hline & & CBR & $\underset{\left(\mathrm{kg} / \mathrm{cm}^{2}\right)}{\mathbf{q u}}$ & & & & \\
\hline Alcoa-Australia [16] & coarse BR & $\begin{array}{l}55 \\
48 \\
\end{array}$ & & soaked unsoaked & & & \\
\hline Hindalco-India [10] & $\mathrm{BR}$ & $\begin{array}{l}2 \\
5\end{array}$ & & soaked unsoaked & & & \\
\hline $\begin{array}{c}\text { Jacobs Babtie- G. Britain } \\
{[14]}\end{array}$ & $\mathrm{BR}$ & & & & 0.26 & 42 & \\
\hline Nalco / India $[2,18]$ & $\mathrm{BR}$ & & 1.49 & & & $38-42$ & \\
\hline Cengrs-India [20] & $\mathrm{BR}$ & & & & $0,1-0,2$ & $26-28$ & \\
\hline \multirow{4}{*}{$\begin{array}{c}\text { Aristotle University } \\
\text { of Thessaloniki / } \\
\text { "Aluminium of Greece" } \\
\text { (1994-2002) [12] }\end{array}$} & $\mathrm{BR}$ & $16-22$ & & unsoaked & & & \\
\hline & $\mathrm{BR}+\mathrm{FA}$ & 19 & & $\mathrm{FA}=4 \%$ Fly Ash & 0.4 & 41 & $\begin{array}{c}\text { FA }=4 \% \text { Fly } \\
\text { Ash }\end{array}$ \\
\hline & $\mathrm{BR}+\mathrm{BA}$ & 19 & 1.8 & $\mathrm{BA}=10 \%$ Aggregates & & & \\
\hline & $\mathrm{BR}+\mathrm{BA}$ & & 5.6 & 7 days curing & & & \\
\hline \multirow{2}{*}{$\begin{array}{l}\text { Aristotle University of } \\
\text { Thessaloniki /"Aluminium } \\
\text { of Greece"(2008-2012) [12] }\end{array}$} & $\mathrm{BR}+\mathrm{BA}$ & 26 & 5.4 & soaked & & & \\
\hline & $\mathrm{BR}+\mathrm{BA}$ & $\begin{array}{l}67(97 \% \\
\text { Proctor) }\end{array}$ & & unsoaked & & & \\
\hline BR processedat filter press & $\mathrm{BR}+\mathrm{BA}+\mathrm{FA}$ & $\begin{array}{l}82(90 \% \\
\text { Proctor) }\end{array}$ & & $\begin{array}{c}\text { unsoaked FA=3\% Fly } \\
\text { Ash }\end{array}$ & & & \\
\hline
\end{tabular}

Table 5. Strength characteristics under different soaking conditions

\begin{tabular}{ccccc}
\hline \multirow{2}{*}{ MATERIAL } & \multicolumn{2}{c}{ CBR values (\%) } & \multicolumn{2}{c}{ Uncofined Compression (kg/cm $\left.\mathbf{c}^{\mathbf{2}}\right)$} \\
& $90 / 10(*)$ & $80 / 20(*)$ & $90 / 10(*)$ & $80 / 20(*)$ \\
\hline Soaked specimens & 26 & 27 & 2.8 & 2.9 \\
Unsoaked specimens & 85 & 103 & 7.8 & 9.4 \\
\hline (*) Bauxite Residue / Bauxite Aggregates: $\%$ & & &
\end{tabular}

\section{ADDITIVES AND CURING}

Laboratory testing in the AUTH, over long periods of experimentation, led to some recipes of structural reinforcement of BR. Fly ash, as an additive, seems to improve the shear strength of the by-product but, most probably, the durability of the engineering asset (embankment, road course) as well. However, due to economic reasons, this choice is sustainable only if an electric power station of lignite or charcoal is near the BR production plant.

A more sustainable option to enhance the strength properties of BR is to add bauxite chippings of 1-2 $\mathrm{cm}$ in the mass of the by-product at substantially dry conditions $(\mathrm{W}<10 \%)$. This option has proven beneficial in both engineering applications of Aluminium of Greece, briefly presented hereafter.

Although pozzolanic properties of BR are generally questionable, unconfined compression tests on mixes with limestone aggregates [17] unveiled a strength performance increasing with time (1994-2002). This binding effect of BR, however, has not been fully investigated and cannot be explicitly affirmed.

It is obvious that the performance of the material is very different under soaking and dry conditions (Table 5).

Dry specimens exhibited high strength and, therefore, under similar conditions, no serious distress to the road structure should be expected under heavy loads. Protection of the material against immersion and erosion seemed to be absolutely mandatory. It was mainly the necessity to control water effects that dictated the introduction of fly ash into the mixes. Fly ash seemed to act partly as a hydraulic binder but much more, as an additive to control aggressive water effects.

\section{THE EMBANKMENT PILOT PROJECT}

The pilot project of the embankment construction was designed by AUTH [17, 25]. The construction took place in an area close to the industrial installations of the aluminium production. The site investigation and the scope of the research, finally, led to three distinct constituent materials for the construction of the embankment, at three different sections of the embankment, respectively:

- Material I, natural soil of A-4 group, used as a 'standard' construction material.

- Material II, a 50/50(\%) mixture of a BR and an A-1 soil, with low gradation characteristics.

- Material III, a BR material stabilized with $4 \%$ fly ash.

The embankment, $3 \mathrm{~m}$ high, was designed and constructed (2003) at a crest of $75 \mathrm{~m}$ long and $8 \mathrm{~m}$ wide. It was founded on a non-compressible natural soil shaped at a plane horizontal surface. The whole unpaved earth structure, subjected to heavy loading of 30-50 trucks daily, did not exhibit any signs of significant distress or subsidence (Figure 2) after several years under traffic. No evidence of different performance of the three distinct sections is apparent today. Despite the effect of truck loading and of climatic aggressiveness, the embankment performed absolutely satisfactorily and proves the potential of utilising BR in the construction of earth structures. 


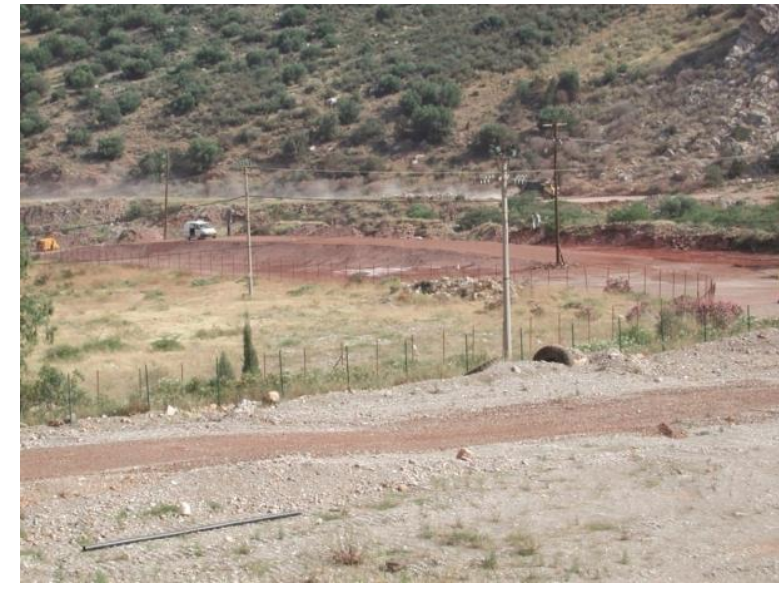

Figure 2. The experimental embankment

\section{THE LOCAL ROAD PROJECT}

Exploring the possibility to introduce processed bauxite in road engineering, 'Aluminium of Greece' carried out a pilot project consisting of laying a BR base course over a wide local trail, in order to provide a roadway of sufficient load resistance. The mix design, laboratory testing and construction guidelines were developed by the Aristotle University [22]. The local road was constructed to bear significant traffic loads, since trucks of gross vehicle weight of 30 tons constituted the main load component on the pavement. The pavement structure should be designed to:

- exhibit sufficient shear strength to bear heavy traffic loads,

- undergo negligible to zero permanent deformation/rutting,

- resist precipitation impact/erosion effects.

The mix design provided an optimum formula of BR 90\%, bauxite chippings $10 \%$ and fly ash $3 \%$ per mix weight. This formula was chosen for application after laboratory experiments on strength properties:

The main earthwork operations were carried out by a grader and a loader [26], laying the material on a $6 \mathrm{~m}$ wide subgrade surface, at a thickness of $12 \mathrm{~cm}$ and a length of $1200 \mathrm{~m}$. Prior to compaction, additional bauxite aggregates, at a rate of $20 \mathrm{~kg} / \mathrm{cm}^{2}$, were spread on the gravel surface (Figure 3 ) to improve bearing capacity. The compaction was carried out by a light non-vibrating roller of 8 tons.

The final outcome was very satisfactory, with the exception of some segments where excessive dust on the pavement surface appeared with time and traffic. The overall performance was very good, accounting for standards of gravel roads. Nevertheless, it was mainly the dust problem that dictated, in 2011, the paving of the roadway by an asphalt concrete layer. In fact, construction of roads and pavements using BR must be associated with environmental protection measures, namely, roadway surfacing.

The engineering assessment took place in 2018, that is, 9 years after the initial construction and 7 years after the surfacing by an asphalt course. Average daily traffic on the asphalt pavement is estimated at 200 trucks, half of which are fully loaded at 30 tons.

The asphalt surface layer exhibits no signs of major distress [26], no local subsidence, no potholes and no severe cracking (Figure 4). Despite the obvious underdesign of the pavement structure, the roadway did not undergo serious damage.

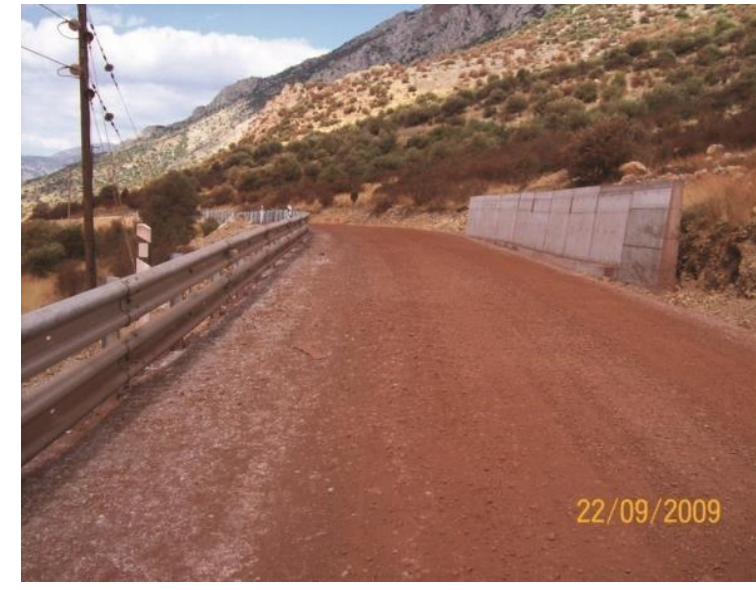

Figure 3. Initial construction of the BR road (2009)

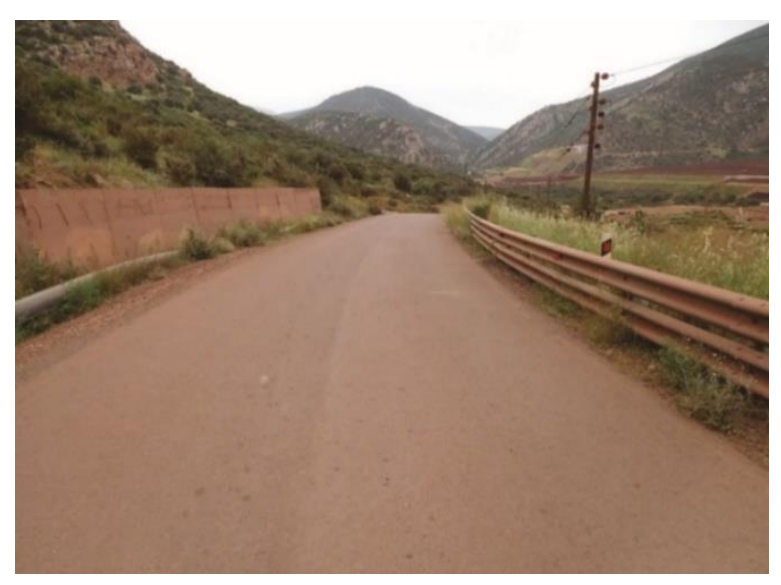

Figure 4. The BR roadway under real traffic conditions in 2018

\section{CONCLUSIONS AND PERSPECTIVES}

$\mathrm{BR}$ is an industrial secondary material produced at large quantities worldwide, thus posing serious problems of disposal. Engineering applications may constitute a promising field of reutilisation once a satisfactory strength performance of the material is proven.

Related literature presents high disparity of values of strength properties, mainly due to varying chemical composition and physical characteristics. Research in several institutes provided low values of strength characteristics, prohibiting any engineering application. By contrast, long lasting research in the AUTH, substantially completed and confirmed by pilot projects, proved that this secondary material is totally suitable for construction, when processed with some additives, such as fly ash and aggregates, to improve strength properties and durability. Moreover, this long experience of AUTH on BR properties and potential applications confirmed that high concentration of iron and calcium oxides is a requisite for high strength properties and for implementation in engineering projects.

Reasonably, BR can be introduced in engineering projects in the vicinity of the processing plant of aluminium after a comprehensive design study and laboratory testing. However, the transport cost of the by-product, depending on the transport distance, may be significant and this may turn into a real impediment to a wide range application of BR. In 
countries where limestone aggregates and natural gravel are abundant, this constitutes a serious drawback. This explains why, in the case of 'Aluminium of Greece', the prospective engineering projects under way, such as local and regional roads introducing BR as main constituent, seem to be limited to the greater area surrounding the industrial plant of alumina production.

A convincing policy to efficiently handle this issue may be drawn by institutional initiatives and reforms from national and regional authorities and, much more, by public-private partnerships to fully explore the potential of reutilisation of this by-product.

\section{REFERENCES}

[1] European Commission. (2017). Circular Economy Research and Innovation: Connecting Economic and Environmental Gains. Report. https://isabelproject.eu/item/circular-economy-research-andinnovation-connecting-economic-environmental-gains/.

[2] National Asphalt Pavement Association. (2017). Asphalt Pavement Industry Survey on Recycled Materials and Warm-Mix Asphalt Usage. 8th Annual Asphalt Pavement Industry Survey, IS 138.

[3] Schimmoller, V.E., Rohrbach, G.J., Holtz, K., Schaftlein, S., Eighmy, T.T., Campbell, R.D., Wiles, C., Van Deusen, C.H., Smith, M., Ford, B., Malasheskie, G., Almborg, J.A. (2000). Recycled materials in European Highway Environments. Uses, Technologies and Policies. Federal Highway Administration U.S. Department of Transportation Washington, D.C.

[4] Tsohos, G., Mouratidis, A. (2002). Effective utilization of fly ash in road construction. Studies in Environmental Science, 48:561-568. https://doi.org/10.1016/S0166-1116(08)70448-5

[5] Mouratidis A., Kehagia F. (2005). Use of steels slags in skid-resistant pavements. Proc. 2nd National Congress of Highway Engineering, Volos.

[6] Manthos, E., Ridondelli, G., Betti, G., Marradi, A. (2015). Preliminary assessment on the use of scrap glass to produce asphalt mixtures. 6th international Conference 'Bituminous Mixtures and Pavements'. https://doi.org/10.1201/b18538-90

[7] FHWA. The Use of Recycled Tire Rubber to Modify Asphalt Binder and Mixtures. TechBrief, FHWA-HIF14-015, 2014.

[8] Gore, M. (2015). Geotechnical Characterization of bauxite residue. Dissertation Thesis, University of Texas at Austin.

[9] Paramguru, R.K., Rath, P.C., Misra, V.N. (2005). Trends in red mud utilization-A review. Mineral Processing \& Extractive Metall. Rev., 26(1): 1-29. https://doi.org/10.1080/08827500490477603

[10] Regional Laboratory of Bridges and Roadways (LRPC) in Aix-en-Provence, Utilisation of bauxite residue in road construction, Technical Report, 1977.

[11] Klauber, C., Gräfe, M., Power, G. (2009). Review of bauxite residue re-use options. CSIRO DocumentDMR3609.

[12] Capron, T.L. (1998). An evaluation of alternative bauxites for Kaiser's Bayerplant in Gramercy Louisiana. Light Metals, 11-14.
[13] Mohapatra, B.K., Rao, M.B.S., Rao, R.B., Paul, A.K. (2000). Characteristics of red mud generated at NALCO refinery, Damanjodi, India. Light Metals, pp. 161-170.

[14] Rao, C.V.H., Naidu, G., Satyanayarana, P.V.V., Adiseshu, S. (2012). Application of GGBS stabilized red mud in road construction. IOSR Journal of Engineering (IOSRJEN), 2(8): 14-20. https://doi.org/10.9790/3021-02841420

[15] Nikraz, H.R., Jitsangiam, P. (2013). Coarse bauxite residue for roadway construction materials. Journal of Pavement Engineering, 14(3): 265-273. https://doi.org/10.1080/10298436.2012.705843

[16] Wang, P., Liu, D.Y. (2012). Physical and chemical properties of sintering red mud and bayer red mud and the implications for beneficial utilization. Materials (Basel), 5(10):

1800-1810. https://doi.org/10.3390/ma5101800

[17] Mouratidis, A., Nikolidakis, P. (1996). On the use of red mud in highway engineering. Proc.of the 2nd Hellenic Congress on Asphalt Mixes and Pavements, Thessaloniki, Greece, pp. 441-452.

[18] Nikraz, H.R., Jitsangiam, P., Jamieson, E. (2008). Sustainable use of a bauxite residue in terms of roadway materials. Proc. 3rd Int. Conf. on Sustainability, Engineering and Science.

[19] Schwarz, M., Lalik, V. (2012). Possibilities of exploitation of bauxite residue from alumina production. Recent researches in metallurgical engineering-from extraction to forming. Recent Researches in Metallurgical Engineering-From Extraction to Forming, $1-22$.

[20] Das, K.S., Rout, S., Alam, S. (2015). Characterisation of red mud as a subgrade construction material. Proc. 3rd Conf. of Transport Research Group, India.

[21] Deelwal, K., Dharavath, K., Kulshreshtha, M. (2014). Evaluation of characteristic properties of red mud for possible use as a geotechnical material in civil construction. IJAET, 7(3): 1053-1059.

[22] Kehagia, F. (2014). Construction of an unpaved road using industrial by-products. Transactions WSEAS on Environment and Development, 10: 160-168.

[23] Newson, T., Dyer, T., Adam, C., Shrap, S. (2006). Effect of structure on the geotechnical properties of bauxite residue. Journal of Geotechnical and Geoenvironmental Engineering, 132(2). https://doi.org/10.1061/(ASCE)10900241(2006)132:2(143)

[24] Sundaram, R., Gupta, S. (2010). Constructing Foundations on Red Mud. 6th Int. Conf. Env. Geotechnics, N. Delhi, India, pp. 1172-1175.

[25] Kehagia, F. (2010). A successful pilot project demonstrating the re-use potential of bauxite residue in embankment construction. Recourses, Conservation and Recycling, 54(7): 417-421. https://doi.org/10.1016/j.resconrec.2009.10.001

[26] Mouratidis, A., Pernientaki, I. (2018). Engineering Assessment of a local Road Constructed from bauxite residue. $9^{\text {th }}$ Int. Conf. on Waste Management and the Environment, Sevilla, pp. 101-109. https://doi.org/10.2495/WM180101

[27] Kishan, D., Kushwaha, S., Dindorkar, N. (2017). Geotechnical properties and strength characterisation of bauxite residue. Int. Journal of Civil Engineering and Technology, 8(7): 346-357. 


\section{NOMENCLATURE}

LOI

$\mathrm{pH}$

BR

WL

PL

IP

W

Wopm

CBR
Loss on Ignition

Alkalinity

Bauxite Residue

Liquidity Limit

Plasticity Limit

Plasticity Index

Water Content

Optimum Water content

California Bearing Ratio $\mathrm{qu}_{\mathrm{u}}$

$\mathrm{c}$

BA

FA

unconfined compressive strength

cohesion

\section{Greek symbols}

$\gamma$

$\phi \quad$ friction angle 